\title{
PERSONHOOD: THE RIGHT TO BE LET ALONE
}

\section{J. Braxton Craven, JR.*}

The great freedoms enumerated in the first ten amendinents to the Constitution are known to most Americans by name-speech, press, religion, etc. But there is another great freedom that has not yet been christened. It is so vast that a single word does not encompass it. It is not an enumerated or "fundamental" freedom, ${ }^{1}$ but to the average man, who may not wish to make a speech or print a newspaper, it may be the greatest freedom of them all. The right to be let alone is the only nonpolitical protection for that vast array of human activities which, considered separately, may seem trivial, ${ }^{2}$ but together make up what most individuals think of as freedom. I am thinking of little things, mostly taken for granted, such as the right to attend a football game, to refrain from attending a political rally, to wear a hat, or to ride a bicycle to work through city traffic. I am concerned for these freedoms because judicial consideration of them is presently unstructured. Because judges do not know low to treat them, there is a danger that they will be undervalued in the courts. ${ }^{3}$ Although I do not think that these rights

* Circuit Judge, United States Court of Appeals, Fourth Judicial Circuit. A.B. Duke University, 1939; LL.B. Harvard University, 1942.

1. Irving Brant undertook the task of compilation and uncovered sixty-three specific guarantees contained in the Constitution and its amendments. I. BraNT, THE BILL of Rights 8-15 (1965). Counting seven principles of government, "the first of which is the existence of a written Constitution," id. at 8, Brant concluded that there were twenty-four elements of a bill of rights in the original Constitution. Taking account of multiple protections in a single amendment, he added thirty guarantees of freedom derived from the first ten amendments, making fifty-four "rights" "that date back to the beginning of our present form of government." Id. at 14. Mr. Brant added nine libertarian provisions derived from the thirteenth, fourteenth, fifteenth, nineteenth and twenty-fourth amendments, "asserted either as positive rights or as restraints upon state action," id. at 15, making a grand total of sixty-three specific guarantees contained in the Constitution and its amendments and constituting our American Bill of Rights. Id.

2. The Supreme Court is aware that lesser rights may be as highly valued as more fundamental ones. In assessing the magnitude of the right to travel abroad, the Supreme Court expressed its awareness of the importance of other "lesser" rights:

Travel abroad, like travel within the country, may be necessary for a liveli-

hood. It may be as close to the heart of the individual as the choice of what

he eats, or wears, or reads. Kent v. Dulles, 357 U.S. 116, 126 (1958) (empha-

sis added).

3. This Article will not attempt to vindicate these "lesser rights" against private parties. This fight appears to be best left to legislative, rather than judicial, innovation. Cf. Bellamy v. Mason's Stores, Inc., 508 F.2d 504 (4th Cir. 1974). 
depend upon the doctrine of substantive due process, ${ }^{4}$ there is undeniably a relationship and the demise of that doctrine threatens their vindication.

Under the currently sanctioned judicial approach, a litigant challenging a state regulation in a federal court must first demonstrate that such regulation infringes upon an enumerated or fundamental right. ${ }^{5}$ If he is successful in meeting this burden, the state will be called upon to show that, nevertheless, the regulation is justified as promoting a "contpelling" state interest. ${ }^{\circ}$ This approach works quite well where the individual, perhaps with some help from the Justices, ${ }^{7}$ is able to trace his asserted interest to its constitutional source. The list of such rights, however, is obviously exhaustible. At some point between the right to liave an abortion ${ }^{8}$ and the right to an education ${ }^{9}$ the constitutional framework becomes overburdened. Under the current approach, having failed to establish his asserted right as "fundamental," the litigant is normally left remediless. ${ }^{10}$ Thus legislatures are left virtually free,

4. Substantive due process is synonymous with Lochner v. New York, 198 U.S. 45 (1905). In Lochner, the Supreme Court struck down a New York statute regulating the hours a baker could work on the grounds that the statute interfered with the right of contract between an employer and his employees, a right found to be part of the liberty protected by the fourteenth amendment. Id. at 53. Lochner is the paradigm of "legislative" judicial review. It has long been disparaged as an extreme example of the judicial branch substituting its judgment for that of Congress and state legislatures. See Brown, Due Process of Law, Police Power, and the Supreme Court, 40 HaRv. L. Rev. 943 (1927); McCloskey, Economic Due Process and the Supreme Court: An Exhumation and Reburial, 1962 Sup. CT. REv. 34, 36-40.

5. The Supreme Court has labeled "fundamental" those rights which are "implicit in the concept of ordered liberty." Palko v. Connecticut, 302 U.S. 319, 325 (1937). Although the precise scope of this definition has never been determined, see Adamson v. California, 332 U.S. 46, 53-55 (1947), it is certain that some rights not explicitly named in the Constitution are nonetheless protected. See, e.g., Roe v. Wade, 410 U.S. 113 (1973).

6. See, e.g., Kramer v. Union Free School Dist., 395 U.S. 621, 627 (1969); Shapiro v. Thompson, 394 U.S. 618, 634 (1969); Sherbert v. Verner, 374 U.S. 398, 406 (1963).

7. For example, counsel for appellants in Griswold v. Connecticut, 381 U.S. 479 (1965), asserted that a right to use contraceptives could be derived from the guarantees of the first, third, fourth, fifth, and fourteenth amendments. Brief for Appellant at 7983. Mr. Justice Douglas' majority opinion found that the right was a part of the "penumbra" formed by emanations from these amendments. 381 U.S. at 484 . See Emerson, Nine Justices in Search of a Doctrine, 64 MicH. L. Rev. 219, 228-29 (1965). See also Clark, Constitutional Sources of the Penumbral Right to Privacy, 9 VILL. L. Rev. 833 (1974); Wheeler \& Kovar, Roe v. Wade: The Right of Privacy Revisited, 21 U. KAN. L. REv. 527 (1973).

8. See Roe v. Wade, 410 U.S. 113, 153-54 (1973).

9. See San Antonio Independent School Dist. v. Rodriguez, 411 U.S. 1, 35 (1973).

10. Absent a fundamental right, the state need only show a rational relation between the regulation in question and a legitimate state interest. Ferguson v. Skrupa, 372 U.S. 726 (1963). See notes 76-77 infra and accompanying text. 
within political bounds, to honor or deny at their pleasure riglits of persons that are not "fundamental."

This Article will suggest how these less important rights-which can be collectively termed a right of "personhood"-can be given meaningful protection without awakening the long dormant shade of Lochner. What I suggest is the judicial recognition of a universal right of "personhood" which protects individuals from arbitrary and capricious governmental action, but which, in appropriate situations, can be outweighed by a demonstrated state interest. ${ }^{11}$ This right, while concededly not "fundamental" in stature, comes within the protection of the ninth amendment ${ }^{12}$ and the due process clauses of the fifth and fourteenth amendments. ${ }^{13}$ Actions alleging violations of this right should, there-

11. An implied additional requirement is that the alleged state interest be sufficient to outweigh the state's frequently overlooked interest in fostering a society which values individual liberty. See Henkm, Privacy and Autonomy, 74 Colum. L. Rev. 1410, 143031 (1974).

12. The ninth amendment states that the Constitution's enumeration of some rights "shall not be construed to deny or disparage others retained by the people." U.S. CoNST. amend. IX; see Griswold v. Connecticut, 381 U.S. 479, 486-99 (1965) (Goldberg, J., concurring); Dixon, The Griswold Penumbra: Constitutional Charter for an Expanded Law of Privacy?, 64 Mich. L. Rev. 197, 207 (1965). While I agree with Professor Monaghan that the ninth amendment is a bottomless and presently empty well if viewed as a source of fundamental rights, Monaghan, The Supreme Court, 1974 TermForeword: Constitutional Common Law, 89 HaRv. L. Rev. 1, 45 (1975), I do think that it clearly indicates an intention by the framers to provide some constitutional protection for lesser rights. See Comment, Unenumerated Rights-Substantive Due Process, The Ninth Amendment, and John Stuart Mill, 1971 WIsc. L. REv. 922, 927-28. See generally Paust, Human Rights and the Ninth Amendment: A New Form of Guarantee, 60 CoRnell L. Rev. 231 (1975); Rhoades \& Patula, The Ninth Amendment: A Survey of Theory and Practice in the Federal Courts Since Griswold v. Connecticut, 50 DENVER L.J. 153 (1973).

13. No person shall be "deprived of . . . liberty ... without due process of law." U.S. Const. amend. V, XIV. The Supreme Court has acknowledged that the scope of this guarantee is broad:

Although the Court has not assumed to define "liberty" with any great precision, that term is not confined to mere freedom from bodily restraint. Liberty under law extends to the full range of conduct which the individual is free to pursue, and it cannot be restricted except for a proper governmental objective. Bolling v. Sharpe, 347 U.S. 497, 499-500 (1954).

The First Circuit expressed the same thought in a high school hair regulation case: "[L]iberty" seems to us an incomplete protection if it encompasses only the right to do momentous acts, leaving the state free to interfere with those personal aspects of our lives which have no direct bearing on the ability of others to enjoy their liberty. ... Indeed, a narrower view of liberty in a free society might, among other things, allow the state to require a conventional coiffure of all its citizens, a governmental power not unknown in European history.

We think the Founding Fathers understood themselves to be limiting the government's power to intrude into this sphere of personal liberty by reserving some powers to the people. ... The Founding Fathers wrote an amendment for speech and assembly; even they did not deem it necessary to write an amendment for personal appearance. We conclude that within the commodious concept of liberty, embracing freedoms great and small, is the right to wear 
fore, be cognizable in the federal courts. ${ }^{14}$

It is too soon to attempt a precise definition of the term "personhood." The term, which originated with Professor Paul Freund, ${ }^{15}$ includes elements of the concepts of individuality, autonomy, and privacy, but none of these words is sufficient. ${ }^{18}$ The "right to be let alone" expresses the idea, but those words have become too much associated with fourth amendinent-type freedom. The original meaning of the phrase, however, as captured by Justice Brandeis in his dissent in Olmstead v. United States, ${ }^{17}$ comes very close to the principle which I have in mind:

The makers of our Constitution undertook to secure conditions favorable to the pursuit of happiness. They recognized the significance of man's spiritual nature, of his feelings and of his intellect. They knew that only a part of the pain, pleasure and satisfaction of life are to be found in material things. They sought to protect Americans in their beliefs, their thoughts, their emotions and their sensations. They conferred, as against the Government, the right to be let alone-the most comprehensive of rights and the right most valued by civilized men. To protect that right, every unjustifiable intrusion by the Government upon the privacy of the individual, whatever the means employed, must be deemed a violation of the Fourth Amendment.18

one's hair as he wishes. Richards v. Thurston, 424 F.2d 1281, 1284-85 (1st Cir. 1970) (footnotes omitted).

14. Federal judicial power extends "to all Cases . . . arising under [the] Constitu- . tion . . . ." U.S. CoNST. art. III, § 2.

15. In his dinner address to the American Law Institute on May 23, 1975, Professor Freund said:

The theme of personhood is . . emerging. It has been groping, I think, for a rubric. Sometimes it is called privacy, inaptly it would seem to me; autonomy perhaps, though that seems too dangerously broad. But the idea is that of personhood in the sense of those attributes of an individual which are irreducible in his selfhood. We all know the agonizing judgments that have had to be made and that will have to be made in such diverse areas as abortion and the death penalty, which it seems to me are aspects of this issue of personhood. In the future, this issue is likely to loom ever larger as we see advances in the biomedical sciences that will lead to genetic engineering and the kinds of precise behavior control that will test our conceptions of individual responsibility and individuality. AMERICAN LaW INSTITUTE, 52ND ANNUAL MEeTING 42-43 (1975).

16. "Privacy" has acquired a secondary meaning since Warren and Brandeis used the term some 86 years ago to refer to protection of one's papers and effects from disclosure and publication by the media. Warren \& Brandeis, The Right to Privacy, 4 Harv. L. Rev. 193 (1890). I suppose the paradigm of this sort of right of privacy was illustrated on the CBS program Sixty Minutes on December 21, 1975, when it was contended that the right of privacy protects the identity of a medical doctor who grossed almost $\$ 500,000$ in Medicaid payments from the Department of Health, Education and Welfare. That is not what $I$ have in mind.

17. 277 U.S. 438 (1928), overruled, Katz v. United States, 389 U.S. 347, 352-53 (1967).

18. 277 U.S. at 478 (Brandeis, J., dissenting). 
Personhood is, as Professor Freund put it, "groping . . . for a rubric."19 Perhaps, though, if we turn to our traditions, and resort to the case method, theory and a name will einerge.

The need for a doctrine of personhood as well as the shortcomings of the current judicial approach are illustrated by the Supreme Court's recent decision in Kelley v. Johnson. ${ }^{20}$ The case involved a challenge to a police department's hair grooming regulation. The Court had previously refused to consider "hair cases,"21 despite the fact that the circuits have reached inconsistent results and have employed varying approaches ${ }^{22}$ - a schoolboy in the Fourth Circuit has a greater constitutional interest in his hairstyle than does his contemporary to the south. ${ }^{23}$ Kelley provided the Court with an opportumity to relieve us of this strange situation.

In earlier times, the Court would likely have presented the dissident officer with a simple choice: get a haircut or quit the force. ${ }^{24}$ Public employment has smce been recognized as a right rather than a privilege ${ }^{25}$ and the government is restramed from conditioning employment upon the employee's relinquishment of another constitutional right. ${ }^{26}$ Following this analysis, the Kelley Court set out to decide whether a policeinan has a constitutional right to wear his hair in a style that pleases him. This task did not prove to be difficult. There is not one word or clause or

19. See note 15 supra.

20. 96 S. Ct. 1440 (1976).

21. We had previously been given a few glimpses of the Court's attitude toward constitutional challenges to hair regulations. Mr. Justice Black, for example, disdainfully denied a motion to vacate a stay of injunction in Karr v. Schmidt, 401 U.S. 1201 (1971):

The only thing about [the case] that borders on the serious to me is the idea that anyone should think the Federal Constitution imposes on the United States courts the burden of supervising the length of hair that public school students should wear. Id. at 1202-03.

Mr. Justice Douglas was somewhat more sympathetic to the plight of longhaired schoolboys. See Olff v. East Side Union High School Dist., 404 U.S. 1042 (1972) (dissenting from denial of cert.); Ferrell v. Dallas Independent School Dist., 393 U.S. 856 (1968) (dissenting from denial of cert.).

22. See notes $47-51$ infra and accompanying text.

23. Compare Massie v. Henry, 455 F.2d 779 (4th Cir. 1972), with Karr v. Schinidt, 460 F.2d 609 (5th Cir.), cert. denied, 409 U.S. 989 (1972).

24. As Mr. Justice (then Judge) Holmes stated in a first amendment context: "The petitioner may have a constitutional right to talk politics, but he has no constitutional right to be a policeman." McAuliffe v. Mayor of New Bedford, 155 Mass. 216, 220, 29 N.E. 517 (1892).

25. See Van Alstyne, The Demise of the Right-Privilege Distinction in Constitutional Law, 81 HaRv. L. Rev. 1439, 1463-64 (1968).

26. Keyishian v. Board of Regents, 385 U.S. 589, 605-06 (1967) (citing cases); see Van Alstyne, The Constitutional Rights of Public Employees: $A$ Comment on the Inappropriate Uses of an Old Analogy, 16 U.C.L.A. L. REv. 751 (1969). 
phrase in the Constitution or the Bill of Rights addressed to hirsute appearance. That leaves us with the due process clause of the fourteenth amendment or the penumbras of the first ten amendments. It is true that the Supreme Court has gone beyond the face of the Bill of Rights to find several fundamental rights ${ }^{27}$ and has established a somewhat vague zone of autonomy around individuals to shield them from overly intrusive governmental action. In Griswold v. Connecticut, ${ }^{28}$ the Court held that a married couple's use of contraceptives was within this zone, ${ }^{20}$ and in Roe $v$. Wade ${ }^{30}$ this fundamental right of privacy was deemed "broad enough to encompass a woman's decision whether or not to terminate her pregnancy."31 The momentousness of these decisions, however, suggests that this method of constitutional adjudication would not be extended to cover the comparatively trivial imdividual decision of when to visit a barber. ${ }^{32}$ This, of course, was what the Court decided. Since the policeman had no fundamental right to groom his hair as he wished, he was not entitled to Roe-type protection and the state was only required to pass the rational relationship test. ${ }^{33}$

But Roe-type protection is extreme. It virtually preempts the field in favor of the person and against the state. There must be something in between, and, if there is, personhood is not doomed.

That an asserted right cannot be found in the Constitution ought to be the beginning of mquiry rather than the end of it. How many personal rights of Americans are there? Has anyone ever attempted a compilation? ${ }^{34}$ I suppose the beginning point of analysis is the recognition of a basic weakness in the Constitution. As Mr. Brant stated, the document "as a charter of freedoin . . . was woefully deficient."35

27. See, e.g., Kramer v. Union Free School Dist, 395 U.S. 621 (1969) (right to vote); Shapiro v. Thompson, 394 U.S. 618 (1969) (right to travel interstate); Skinner v. Oklahoma, 316 U.S. 535 (1942) (right to procreate).

28. 381 U.S. 479 (1965).

29. Id. at 485.

30. 410 U.S. 113 (1973).

31. Id. at 153.

32. For a consideration of possible constitutional sources of a right to wear long hair, see 84 HaRv. L. REv. 1702, 1707-12 (1971).

33. The state easily passed this test, asserting that the hair regulation promoted the governmental interest in having an identifiable police force and in maintaining the esprit de corps of the gendarmerie. $96 \mathrm{~S}$. Ct. at 1446.

34. See note 1 supra.

35. BRANT, supra note 1 , at 3 . It is interesting to note that the right to assemble, certainly now deemed fundamental, almost escaped constitutional recognition. Mr. Sedgwick of Massachusetts argued that it was "derogatory to the dignity of the House to descend to such minutiae . . ." and equated freedom of assembly with the right of a man "to wear his hat if he pleased; . . . get up when he pleased, and go to bed when he thought proper. . . ." Id. at 54 . 
This is because the founders were not primarily concerned with the safeguarding and implementation of personal liberty ${ }^{36}$ but concentrated instead upon the matter at hand: the establishment of a national governinent. Even the Bill of Rights was added to the Constitution as a second thought, mostly to pacify recalcitrant states ${ }^{37}$ and recalcitrant people in all the states. As Professor Goebel pointed out, the Constitutional Convention was not preoccupied with liberty. Indeed, "no word in the vocabulary of contemporary politics was used less often. Neither the task nor the idiom of discussion required it. 'We are not working on the natural rights of mon not yet gathered into society,' wrote Randolph, 'but upon those rights modified by society and imterwoven with what we call the rights of states." "38 The phrase "blessmgs of liberty" was put into the Preamble as a last-minute inspiration of Gouverneur Morris and was not even debated..$^{39}$

It is significant that the very form of recognition of personal rights in the Constitution and the Bill of Rights is in the negative. Nowhere is there an affirmative grant of rights to the people. Instead, the whole docunnent witli respect to the rights of persons is a negative series of restrictions upon the power of government. Three sets of words-in the Declaration of Independence, the Preamble to the Constitution, and the minth amendment-make it clear, beyond argument I think, that the

36. Many of the founders believed in natural law. North Carolina's "Declaration of Rights," laid before the Congress before we joined the Union, is typical of many adopted in the States. The first proposition reads as follows:

1. That there are certain natural rights, of which men, when they form a social compact, cannot deprive or divest their posterity, among which are the enjoyment of life and liberty, with the means of acquiring, possessing, and protectimg property, and pursuing and obtaining happiness and safety. $4 \mathrm{~J}$. ELliot, The Debates in the Several State Conventions 243 (1937) (emphasis added).

37. North Carolina, for example. Even North Carolinians did not think that the Bill of Rights was an exhaustive enumeration of the rights retained by the people. Hear James Iredell:

The gentleman says that unalienable rights ought not to be given up. Those rights which are unalienable are not alienated. They still remain with the great body of the people. If any right be given up that ought not to be, let it be shown. Say it is a thing which affects your country, and that it ought not to be surrendered: this would be reasonable. But when it is evident that the exercise of any power not given up would be an usurpation, it would be not only useless, but dangerous, to enumerate a number of rights which are not intended to be given up; because it would be implying, in the strongest manner, that every right not included in the exception might be impaired by the government without usurpation; and it would be impossible to enumerate every one. Let any one make what collection or enumeration of rights he pleases, I will immediately mention twenty or thirty more rights not contained in it. $4 \mathrm{~J}$. ELLIOT, supra note 36, at 166-67 (emphasis added).

38. 1 J. Goebel, History of the Supreme Court of the United States: ANTECEDENTS AND BEgINNINGS To 1801238 (1971) (Vol. 1 of Oliver Wendell Holmes Devise series).

39. Id. 
rights of persons in the United States are not confined to those specifically recognized. The Declaration declares it to be true that "all men are endowed, by their creator, with certain unalienable rights [and] that among these are life, liberty and the pursuit of happiness." 40 Indeed, these rights are so important that it is for the very purpose of securing them that governments are instituted anong men. The Declaration says so. Faithful to that purpose the Constitution was ordained and established "to promote the general Welfare, and secure the Blessings of Liberty to ourselves and our Posterity." 11 And consistent with both, the ninth amendinent provides that the enuineration in the Constitution of certaim rights shall not be construed to deny or disparage others retained by the people. ${ }^{42}$

To define liberty is to confine it and to that extent to deny it. How many words, how many pages, how many volumes, would it take to delineate perfectly every right of a person residing in these United States? It is mind-boggling to contemplate merely histing every item of food that one may lawfully consume. It would be a frightening task if undertaken with the knowledge that inadvertent omission of bluefish would inean pompano forever. If every area of liuinan activity were included, and it would liave to be upon pain of deprivation, I should think a new Library of Congress would be needed to house only one copy of these laws of permission.

If we must abandon the idea of a compilation of all of the rights of man, and I think we must, then it seems to ine we are driven to an opposite position. An individual should retain the right to engage in any form of activity unless there exists a countervailing state interest of sufficient weight to justify restricting his conduct. This is the essence of personhood: a rebuttable presumption that all citizens have a right to conduct their lives free of government regulation. At a minimum, personhood should enconipass "the freedom to do everything which injures no one else." ${ }^{343}$ In John Stuart Mill's words:

40. DECLARATION OF INDEPENDENCE.

41. U.S. CONST. preamble.

42. U.S. CONST. amend. IX; see Rogge, Unenumerated Rights, 47 CaLIF. L. Rev. $787,787-93$ (1959).

43. Declaration of the Rights of Man and Citizen (1789), reprinted in THE CONstitutions and Other Select Documents Illustrative of the History of France 1789-1907 (Anderson ed. 1967). It is indeed unsettling that this idea is nearly as revolutionary today as it was in 1789 . Recent decisions dealing with private sexual activity, however, indicate that the liberation of "victimless" conduct from state supervision is a long way off. See, e.g., Lovisi v. Slayton, No. 73-2337 (4th Cir. May 12, 1976) (holding that the enforcement of a state anti-sodomy statute did not violate a married couple's right to marital privacy because of a third party's participation in the prohibited activity); Doe v. Commonwealth's Attomey, 403 F. Supp. 1199 (E.D. Va. 
As soon as any part of a person's conduct affects prejudicially the interests of others, society has jurisdiction over it, and the question whether the general welfare will or will not be promoted by interfering with it becomes open to discussion. But there is no room for entertaiming any such question when a person's conduct affects the interests of no persons besides himself .... In all such cases, there should be perfect freedom, legal and social, to do the action and stand the consequences. ${ }^{44}$

For example, all would agree that there is a "right" to wear a bathing suit on a public beach. Controversy begins as the suit diminishes. The proper question is not whether a person can or must wear a suit (who would say he must in his own bathtub?) but whether the state's interest in decorous and moral behavior is of greater weight in the particular instance. ${ }^{45}$

Now is an appropriate time to return to the problem of hair. As stated earlier, ${ }^{40}$ the federal courts of appeals which have been confronted with hair cases have reached inconsistent results. Several of them, including the Fourth Circuit, have found in cases concerning school hair regulations that the right to govern one's personal appearance is one aspect of the fundamental liberty protected by the due process clause. ${ }^{47} \mathrm{I}$ am now willing to concede that our brethren in the Fifth, ${ }^{48}$ Sixth, $^{40}$ Ninth, ${ }^{50}$ and Tenth ${ }^{51}$ Circuits were right all along in decidimg that there is no fundamental right to have long hair, and I will also admit that their position provided them with greater flexibility. ${ }^{52}$ I think that the

1975), aff'd mem., $96 \mathrm{~S}$. C. 1489 (1976) (upholding the enforcement of the same statute with regard to private homosexual activity).

44. J. Mill, ON Liberry 92 (Bobbs-Merrill ed. 1956).

45. At this point, we may have lost our friend John Stuart Mill who, I think, would not agree that moral scruples are a sufficient societal interest to justify inhibiting the individual:

Where not the person's own character but the traditions or customs of other people are the rule of conduct, there is wanting one of the principal ingredients of human happimess, and quite the chief ingredient of individual and social progress. Id. at 68.

46. See text accompanying note 22 supra.

47. Stull v. School Board, 459 F.2d 339, 347 (3d Cir. 1972), overruled, Zeller v. Donegal School Dist. Bd. of Educ., 517 F.2d 600, 608 (3d Cir. 1975) (see notes 54-55 infra and accompanying text); Massie v. Henry, 455 F.2d 779, 783 (4th Cir. 1972); Bishop v. Colaw, 450 F.2d 1069, 1075 (8th Cir. 1971); Crews v. Cloncs, 432 F.2d 1259, 1263 (7th Cir. 1970); Richards v. Thurston, 424 F.2d 1281, 1284-85 (1st Cir. 1970).

48. Karr v. Schmidt, 460 F.2d 609, 613 (5th Cir.), cert. denied, 409 U.S. 989 (1972).

49. Gfell v. Rickelman, 441 F.2d 444, 446 (6th Cir. 1971).

50. King v. Saddleback Junior College Dist., 445 F.2d 932, 940 (9th Cir.), cert. denied, 404 U.S. 979 (1971).

51. Freeman v. Fluke, 448 F.2d 258, 260-61 (10th Cir. 1971), cert. denied, 405 U.S. 1032 (1972).

52. See, e.g., Lansdale v. Tyler Junior College, 470 F.2d 659 (5th Cir. 1972), 
dichotomy of results, however, is primarily a function of the strained form of constitutional analysis which we all felt obliged to apply. Those of us who felt that the state was overreaching in attempting to keep hair off the schoolboys' ears and collars were faced with the choice of either finding a constitutional source for the plaintiff's asserted right or upholding the regulation. Under the doctrine of Ferguson v. Skrupa, ${ }^{53}$ there was no middle ground. Problems were encountered when, in subsequent cases, the state's asserted interest appeared inore significant. In Zeller v. Donegal School District Board of Education, ${ }^{54}$ for example, the Third Circuit was put in the embarrassing position of having to withdraw the fundamental right of personal appearance which they had previously extended to schoolboys in order to uphold what they now felt to be a legitimate school regulation. ${ }^{55}$ The Eighth Circuit was forced to assign "compelling interest" status to the government's concern for "the maintenance of an efficient and disciplined police force" and public confidence in order to uphold a regulation of police hair styles. ${ }^{56}$

In the Fourth Circuit, we suffered intramurally and managed to keep most of our anguish out of the Federal Reporter. In Schott v. Fornoff $f^{57}$ we overturned a very specific grooming regulation promulgated by a police chief. ${ }^{68}$ In that short per curiam opinion there is not one word

cert. denied, 411 U.S. 986 (1973) (upholding the right of college students to wear their hair as they please).

53. 372 U.S. 726 (1963). See notes 76-77 infra and accompanying text.

54. 517 F.2d 600 (3d Cir. 1975).

55. The plaintiff had been excluded from the school soccer team for failure to get a haircut. Although only a plurality of four judges joined in the main opinion, a fifth judge agreed that there was no fundamental right involved. Id. at 610 (Rosenn, J., concurring and dissenting).

56. Stranley v. Anderson, 478 F.2d 188, 190 (8th Cir. 1973). The author of the opinion, Judge Lay, later recanted. Rinehart v. Brewer, 491 F.2d 705, 707 n.1 (8th Cir. 1974) (dissenting opinion).

57. S15 F.2d 344 (4th Cir. 1975).

58. The regulation read in pertinent part:

HAIR All male police, cadet and civilian personnel will wear their hair neatly trimmed and tapered to the sides of the head and to the back of the neck.

SIDEBURNS Will be neatly trimmed and will not extend below the midpoint of the Tragus of the ear. The Tragus is identified as the prominence in front of the external opening of the ear.

MUSTACHES No hair will extend down over the upper lip nor extend past either side of the mouth, and must be kept trimmed at all times.

In addition, the regulation included a diagram of a male haircut that conformed to the Chief's expectations. This diagram showed that (1) hair was to extend to a maximum height of two inches above the skull after combing; (2) the maximum thickness of sideburns was to be one-quarter inch; (3) there was to be a one-inch clearance between the collar and the hairline on the back of the head; (4) there was to be a one-quarter inch clearance at all points between the hair on the side of the head and the ear (referred to as the "antiseptic white sidewall rule"). Brief for Appellant, app. at 15, Schott v. Fornoff, 515 F.2d 344 (4th Cir. 1975). 
about Officer Schott's right to wear his hair longer than pleased the Chief. We did not equate his haircut with a personal right deemed fundamental or imphicit in the concept of ordered liberty and therefore included in the guarantee of personal privacy.59 From reading the opinion one cannot even discern recognition on our part that Schott had a right to have any hair at all, much less to decide how it should be cut. Without considering Schott's hair, it was held simply that the hair regulation was so extreme in respect to appearance and cut that it could not be said to bear a rational relationship to the constitutionally permissible objective of administering a police department and, in short, was arbitrary and capricious. There is not even an echo of the cominand in more fundamental areas that sound almost like "Congress shall make no law . . ." Clearly the implication of the opinion is that the state may enter the field, may regulate the appearance of its police-but may not do so without a reason, i.e., arbitrarily and capriciously. ${ }^{60}$

Left on the cutting room floor, wisely in hight of the Supreme Court's decision in Kelley, was a much longer draft which reached the same result from another angle. In that opinion, we reaffirmed our holding in Massie v. Henry ${ }^{61}$ that the right to wear one's hair as he wishes is "an aspect of the right to be secure in one's person guaranteed by the due process clause . . " "62 which can be infringed upon only under special circumstances not present in the case at liand. While we admitted that the Chief was free to control ludicrous or bizarre appearance, we concluded that the detrimental effect of Schott's hairstyle on police morale and public confidence was not sufficient to overcome his assertion of what we deemed a fundamental hiberty.

The reason I am now inclined to favor the short per curiam opinion that was filed over this longer proposed draft is that I think it more accurately portrays how we arrived at our decision. We were willing to acknowledge that appearance does have some bearing on the operation of a police force, but the department in this case failed to show any loss of public confidence and indeed admitted that Schott was chosen for certain special assignments in part because of his attractive personal appearance. It was unnecessary to decide whether or not tonsorial appearance is constitutionally protected since, whatever its status, it

59. See Roe v. Wade, 410 U.S. 113,152 (1973).

60. Mr. Justice Marshall, dissenting in Kelley v. Johnson, 96 S. Ct. 1440 (1976) agreed that although the state's interests in an identifiable and well-motivated police force are legitimate, hair length regulations bear no rational relationship to these goals. Id. at 1449-50.

61. 455 F.2d 779 (4th Cir. 1972).

62. Id. at 783 . 
outweighed the state's unsupportable interest in regulating such appearance in this instance. ${ }^{63}$

More has been written about hair cases than the reader probably wants to know. ${ }^{64}$ Personhood, however, is not a narrow concept. Included are those myriad activities, decisions, and idiosyncrasies which, in the normal scheme of things, are not considered to be within the ambit of fundamental rights. In a recent unreported case, for example, the Fourth Circuit upheld the constitutionality of a Virginia motorcycle helmet law. ${ }^{65}$ The case, and our disposition of it, further convinced me that personhood is not a fundamental liberty protected by the due process clause of the fourteenth amendinent or the penumbras of others,

63. Because we did not adjudicate the constitutional magnitude of the plaintiff's asserted right, I believe that Schott survives Kelley v. Johnson, 96 S. Ct. 1440 (1976). "The constitutional issue to be decided . . . " the Court stated, "is whether [the state's] determination that such regulations slould be enacted is so irrational that it may be branded 'arbitrary' . . . ." Id. at 1446. In Schott we so held.

64. If not, see Comment, Long Hair and the Law: $A$ Look at Constitutional and Title VII Challenges to Public and Private Regulation of Male Grooming, 24 U. KAN. L. Rev. 143 (1975); 84 HaRv. L. Rev. 1702 (1971).

65. United States v. Davy, No. 75-2215 (4th Cir. Jan. 8, 1976). The entire opinion reads as follows:

\section{PER CURIAM}

Bruce R. Davy, convicted of riding a motorcycle without a helmet on the George Washington Memorial Parkway, a violation of $\S 46.1-172$ of the 1950 Code of Virginia (as amended), and made a federal offense by 18 U.S.C. $\$$ 13, appeals pro se, asserting the unconstitutionality of the statute which makes mandatory the use of protective headgear while operating a motorcycle. He urges that $\S 46.1-172$ violates numerous segments of the United States Constitution including the privileges and immunities clause (Art. IV, $\$ 2$ ), and the ninth, tenth, and fourteenth amendments.

Essentially Davy's argument is that the statute in question should be characterized as an unconstitutional exercise of the police power of the state. We disagree. A state has broad powers to establish and enforce standards for the purpose of protecting the health and safety of its citizens. Barsky v. Board of Regents, 347 U.S. 442,449 (1954). Requiring safety helmets for motorcyclists is within the police power. See State $\nu$. Anderson, 275 N.C. 168, 166 S.E.2d 49. Contra People v. Fries, 42 III. 2d 446, 250 N.E.2d 149 (1969).

It is clear that unless the exercise of police power in question infringes upon some constitutionally fundamental interest, it need only bear a rational relationship to a legitimate governmental interest. Friendship Medical Center, Ltd. v. Chicago Board of Health, 505 F.2d 1141, 1149-50 (7th Cir. 1974), cert. denied, 420 U.S. 997 (1975). Since we do not find the right to ride a motorcycle helmetless to be a "personal right[ ] that can be deemed 'fundamental" or 'implicit in the concept of ordered liberty,' ... [and therefore] included in [the] guarantee of personal privacy," we conclude that the traditional rational relationship test must be applied here. See Roe v. Wade, 410 U.S. 113, 152 (1973).

We hold that the government has a legitimate interest in protecting its citizens from injuries and consequent ramifications which necessarily inhere from involvement in accidents which arise from the operation of motorcycles. Safety regulations requiring the wearing of helinets bear a rational relationship to this valid governmental objective, and the statute is therefore constitutional. See Simon v. Sargent, 346 F. Supp. 277 (D. Mass.), aff'd mem., 409 U.S. 1020 (1972).

Accordingly, the judgment of the district court is affirmed. 
but also reinforced my belief that this should not really matter. We found that there existed legitimate governmental objectives which were promoted by the law and, therefore, the "rational relationship" test was met. ${ }^{66}$ We reached this conclusion, however, only after deciding that the right to ride helmetless was not "fundamental," and, therefore, the lesser standard apphed. As any student of constitutional law knows, the "rational relationship" test is not particularly onerous, ${ }^{67}$ at least under due process analysis. ${ }^{68}$ If there is no fundamental right involved, the court will uphold the statute where "any state of facts either known or which could reasonably be assumed affords support for it." right of personhood were recognized, however, the analysis would go something like this: (1) does the proscribed activity harm anyone other than the actor?; (2) what is the state's interest in regulating this conduct?; and (3) does this imterest outweigh the individual's right to be let alone? It should be apparent that, using this approach, personhood inay well encoinpass the right to disregard one's cranial well-being while riding a motorcycle. It is at least arguable that no one other than the rider is legitimately concerned with whether or not he wears a helmet ${ }^{70}$ - most states have had considerable difficulty in articulating a justification for their statute other than a paternalistic concern for the individual. ${ }^{71}$ Finally, even if a convincing rationale is put forth, the social good to be achieved should be assessed in relation to the daniage done to the autonomy of the individual. This, of course, necessitates a balancing of interests which may, and probably will, lead to seemingly inconsistent results. The point is that the present mode of analysis, as evidenced in United States $v$. Davy, ${ }^{72}$ also involves such balancing, but hides the decision-making process under the rubric of fundamental rights.

I have finally reached the crucial question: what is wrong with having courts apply a balancing test when deciding a case involving a confrontation between a non-fundaniental right and a less than compelling

66. See note 65 supra.

67. Nevertheless, in a similar case, Michigan was unable to demonstrate the rational connection between its motorcycle helmet law and the public health or welfare. American Motorcycle Ass'n v. Davids, 11 Mich. App. 351, 158 N.W.2d 72 (1968).

68. See notes 95-112 infra and accompanying text.

69. United States v. Carolene Prod. Co., 304 U.S. 144, 154 (1938).

70. Compare American Motorcycle Ass'n v. Davids, 11 Mich. App. 351, 158 N.W.2d 72 (1968), with Simon v. Sargent, 346 F. Supp. 277, 279 (D. Mass.), aff'd mem., 409 U.S. 1020 (1972).

71. Note, Motorcycle Helmets and the Constitutionality of Self-Protective Legislation, 30 Oнто ST. L.J. 355, 366-77 (1969).

72. See notes 65-66 supra and accompanying text. 
state interest? The Supreine Court has used such balancing in heavyweight bouts between fundamental rights and coinpelling state interests, ${ }^{73}$ so why is it not applicable in the lower flights? I think the answer can be given in one italicized word: Lochner.

Lochner v. New York ${ }^{74}$ may not seein to have inuch to do with personhood and even less to do with how one adorns or protects his head. However, the Court's decision that New York had no business telling a inan how to run his bakery marked the high point of judicial intervention in social and economic affairs. ${ }^{75}$ A gradual abdication of authority followed, culminating in 1963 in Ferguson v. Skrupa. ${ }^{78}$ In that case, the Court officially buried Lochner and "returned to the original constitutional proposition that courts do not substitute their social and econounic beliefs for the judgment of legislative bodies."77

The resurgence of judicial intervention into the realin of social legislation, however, has led soine to wonder whether substantive due process ever really died. In both Griswold v. Connecticut ${ }^{78}$ and Roe v. Wade ${ }^{79}$ the Supreine Court struck down state statutes on the grounds that the regulations infringed upon fundamental, but unenumerated, individual rights. Concurring in Roe, Mr. Justice Stewart stated "that the Gris-

73. See, e.g., Pickering v. Board of Educ., 391 U.S. 563 (1968), in which a teacher's right of free expression was pitted against the state's interest, as an employer, in providing efficient public services. The Court applied a balancing test and decided the teacher's conduct did not sufficiently interfere with school operations to warrant his dismissal. Id. at 572-73. Cf. Tinker v. Des Moines School Dist., 393 U.S. 503, 511 (1969) (student's first amendment rights outweigh state's interest in school order absent threat of a "material and substantial interference with schoolwork or discipline").

74. 198 U.S. 45 (1905). The majority opinion in Lochner was written by Mr. Justice Peckham, of whom this story is told:

"What," [Dean Acheson] asked of [Mr. Justice Holmes], "was Justice Peckham like intellectually?"

"Intellectually?," [Holmes] answered, puzzled. "I never thought of him in that connection. His major premise was 'God damn it!' But he was a good judge." D. ACHESON, MoRNING AND Noon 65 (1965).

75. See note 4 supra. Reexamination of the Court's language suggests that perhaps the opinion was overread:

In every case that comes before this court . . . where the protection of the Federal Constitution is sought, the question necessarily arises: Is this a fair, reasonable and appropriate exercise of the police power of the State, or is it an unreasonable, unnecessary and arbitrary interference with the right of the individual to his personal liberty . . . ? 198 U.S. at 56.

I would suggest that a court which enforces the above standard is hardly overstepping its proper authority.

76. 372 U.S. 726 (1963).

77. Id. at 730. Skrupa closed a circle: the Court was willing to allow the legislature to regulate business in 1877, Munn v. Illinois, 94 U.S. 113 (1877), and again in 1963 in Skrupa, but not in 1905. Lochner v. New York, 198 U.S. 45 (1905).

78. 381 U.S. 479 (1965).

79. 410 U.S. 113 (1973). 
wold decision can be rationally understood only as a holding that the [anti-contraceptive] statute substantively invaded the 'liberty' that is protected by the Due Process Clause of the Fourteenth Amendinent. As so understood, Griswold stands as one in a long line of pre-Skrupa cases decided under the doctrine of substantive due process . . .".80 Mr. Justice Rehnquist has also suggested that Lochner and the recent cases expanding the right of privacy (e.g., Griswold and Roe) are "sisters under the skin." 1 Is it possible, then, to reconcile the discredited substantive due process of Lochner with the currently viable substantive due process of Griswold and Roe? Moreover, has the door to widespread judicial intervention been reopened by the Supreme Court's recognition of fundamental rights not enumerated in the Constitution which can only be overcome by an extraordmary state interest?

It seems to me that when we go outside the terms of the Constitution and discover implied fundamental rights, we are necessarily imputing to others our own set of priorities. Is it not unfair to do so except in the extreme case where we can assert that reasonable men could not disagree? I doubt not that it is important to the point of tears for some high school students (or police officers) to wear their hair as they please, nor that Mary Roe truly considered her right to terminate her pregnancy a fundamental one. Similarly, however, I cannot say that Lochner did not believe with equal fervor in his right to operate his small bakery as he chose. Nor can I say that his behef was irrational; a majority of the Supreme Court members at the time agreed with him. But I think it is clear that in none of these cases would the aggrieved party find umiversal support for his position, and that, therefore, ascribing "fundamental" status to any of these rights would be somewhat disingenuous. To the extent that the Court is willing to create fundamental rights in order to provide constitutional protection in selected cases not involving enumerated rights, I believe that the potential exists for a return to judicial intervention in social and economic affairs as pervasive as that exercised in the days of Lochner.

This judicially perceived necessity to find a fundamental right in order to provide protection can be traced to the emasculation of the "rational basis" test fimalized in Ferguson v. Skrupa. ${ }^{82}$ We are left with a situation in which "certain interests require particularly careful scruti-

80. Id. at 168 (footnote omitted).

81. Rehnquist, Is An Expanded Right of Privacy Consistent with Fair and Effective Law Enforcement?, 23 U. KAN. L. REv. 1, 6 (1974); Roe v. Wade, 410 U.S. 113, 174 (1973) (dissenting opinion).

82. 372 U.S. 726 (1963). See notes 76-77 supra and accompanying text. 
ny of the state needs asserted to justify their abridgement"83 while infringements of lesser interests require no scrutiny at all.

It seems to me that a better approach would be to reverse the order of inquiry and focus first on the state interest asserted to justify a regulation. ${ }^{84}$ The burden should first be placed on the state to show that the purpose being pursued is legitimate and that the means employed are reasonably related to this end. ${ }^{85}$ This approach is not entirely inconsistent with normal trial procedure if we accept that the individual's right of personhood creates a presumption that all regulation of his activity is invalid. ${ }^{86}$ By enacting a statute circumscribing his freedoin, or by denying hin some benefit, the state is, in effect, filing a complaint against him, alleging that his activity is causing some public harm. Since it has initiated the complaint, the state should be made to show the harm-to justify its regulation. This, of course, is the reasoning behind the presumption of innocence in criminal cases. Shifting the initial burden to the government also puts into fairer balance the capacity of the litigants to develop the merits of the questions presented. Until recently, the individual has almost always lost, not necessarily because he was wrong, but often because of his inability to prove that he was right. If you inust prove that you liave a right to practice TM or learn karate or belly dancing, you may as well give up. Who will testify? What exhibits will there be? On the other hand, the state has supposed-

83. Poe v. Ullman, 367 U.S. 497, 543 (1961) (Harlan, J., dissenting).

84. Judge Tuttle made this point in his concurring opinion in Sherling v. Townley, 464 F.2d 587 (5th Cir. 1972), a high school hair case:

It seems to me that the majority opinion in Karr posed the wrong question when it stated it as follows: "Is there a constitutionally protected right to wear one's hair in a public high school in the length and style that suits the wearer?" I would say that the question before the court was rather, "May the principal of a high school or the board of education of a county school system constitutionally deny a public education to a student solely because he elects to wear his hair longer than prescribed by the rigid requirements of the school board?" Id. at 588.

My local radio commentator, not a lawyer, put it this way: "No nice kid will perplex and outrage his elders with long hair, but on the other hand, no nice school principal will expel a kid who does."

85. The idea of shifting the burden to the defendant in certain civil suits is not new. See Keyes v. School Dist., 413 U.S. 189, 209 (1973). In that case, the Supreme Court held that "a finding of intentionally segregative school board actions in a meaningful portion of a school system ... creates a presumption that other segregated schooling within the system is not adventitious." Such a finding then "shifts to those authorities the burden of proving that other segregated schools within the system are not also the result of intentionally segregative actions." $I d$. at 208 . The underlying premise in Keyes, that a history of state wrongdoing justifies the imposition of a presumption against the validity of its acts, is also present in the area of personhood: what is history but the story, repeated time and again, of liberty's miraculous escape from tyranny?

86. See text accompanying note 43 supra. 
ly weighed the competing interests prior to enacting legislation or promulgating regulations, and hopes to achieve a certain result by its action. It should be no problem for the state to recount its deliberations to the court in order to rebut the presumption that the individual should be left alone. This should take care of the frivolous cases. Where the state is unable to articulate any reasons for its regulation, can we not reasonably assume that it has acted arbitrarily?

The case of Eisenstadt $v$. Baird, ${ }^{87}$ although it was purportedly decided under the rational relationship test, illustrates somewhat indirectly the desirability of shifting the initial burden to the government. Like Griswold, this case involved a statute interfering with a person's right to use contraceptives. ${ }^{88}$ Rather than attempting to determine the nature of the plaintiff's asserted right, however, the Court first examined the state's rationale for the legislation. ${ }^{89}$ The Court found that there could be no rational relationship between the operation of the statute and any legitimate state purpose, and declared the law unconstitutional. ${ }^{90}$ By merely reversing the order in which it scrutinized the competing interests, then, the Court avoided the tortuous chore of fimding a constitutional source of the plaintiff's right. ${ }^{91}$ His right to personhood was sufficient to carry the day.

A similar approach could have been used in Griswold. Mr. Justice White asserted that "[a]t most the broad ban is of marginal utility to the declared objective"92 and even a dissenter found the statute to be "uncommonly silly." 93 Why should we go any further? If the state is to infringe upon the personhood of its citizens, it must at least be able to demonstrate that the infringement furthers some legitimate state objective. If the Court had first required such a showing, it would have been

87. 405 U.S. 438 (1972).

88. The statute prohibited the distribution of contraceptives to single persons. Id. at 440-41 \& n.2.

89. Id. at 447-55.

90. Id. at $443,454-55$.

91. The Court acknowledged with apparent relief the conservation of judicial energy which had resulted from this simple reversal process:

Of course, if we were to conclude that the Massachusetts statute impinges upon fundamental freedoms under Griswold, the statutory classification would have to be not merely rationally related to a valid public purpose but necessary to the achievement of a compelling state interest .... But ... we do not have to address the statute's validity under that test because the law fails to satisfy even the more lenient equal protection standard. Id. at $447 \mathrm{n} .7$ (emphasis by the Court).

92. 381 U.S. 479, 507 (1965) (White, J., concurring).

93. Id. at 527 (Stewart, J., dissenting). Counsel for the appellant in Griswold later recounted that "a factual demonstration that the law was arbitrary, unreasonable, capricious, and not reasonably related to a proper legislative purpose did not pose serious difficulties." Emerson, supra note 7, at 219. 
able to dispose of the case without straining the Constitution and virtually foreclosing future regulation in this area. ${ }^{94}$

The only apparent difference between these two cases is that Eisenstadt was analyzed under the equal protection clause of the fourteenth amendment ${ }^{95}$ while Griswold was a due process case. In the last few years there have been indications that, under equal protection analysis, the Supreme Court will undertake to impose a "rational relationship" test which cannot be satisfied by a mere hypothetical or speculative rationale. ${ }^{90}$ This phenomenon has been accomparied by a corresponding reluctance to recognize new fundamental rights or suspect classifications. ${ }^{97}$ The Court has insisted that the challenged classification "rest upon some ground of difference having a fair and substantial relation to the object of the legislation . . . ."98 In Reed $v$. Reed ${ }^{99}$ for example, the Court refused to rule that sex classifications are suspect ${ }^{100}$ and, therefore, did not subject to "strict scrutiny" an Idaho statute which provided that, as between persons equally qualified to administer estates, inales must be preferred to females. ${ }^{101}$ Nevertheless, this did not preclude the Court from assessing the reasonableness of the statute in a meaningful way. Its conclusion was that the regulation represented an "arbitrary legislative choice" which did not promote the asserted objective, reducing the workload of probate courts, in a manner consistent with the equal protection clause. ${ }^{102}$ Similarly, in Stanton v. Stanton ${ }^{108}$

94. A similar situation arose in Cleveland Bd. of Educ. v. LaFleur, 414 U.S. 632 (1974). A school board regulation requiring pregnant teachers to take maternity leave several months before the expected date of birth was held to be violative of the teacher's fundamental right to decide whether and when to have a child. The case could have been decided without an expansion of the right to marital privacy since the Court also found that the regulation had "no rational relationship to the valid state interest[s]" asserted. Id. at 643-46. See note 91 supra.

95. 405 U.S. at 443.

96. See Comment, Fundamental Personal Rights: Another Approach to Equal Protection, 40 U. CHI. L. REv. 807, 817-22 (1973).

97. See, e.g., Lindsey v. Nornet, 405 U.S. 56, $73-74$ (1972); Dandridge v. Williams, 397 U.S. 471, 485 (1970); see Gunther, The Supreme Court, 1971 Term-Foreword: In Search of Evolving Doctrine on a Changing Court: A Model for a Newer Equal Protection, 86 HARv. L. Rev. 1, 12-16 (1972).

98. Stanton v. Stanton, 421 U.S. 7, 14 (1975); Reed v. Reed, 404 U.S. 71, 76 (1971), both cases quoting Royster Guano Co. v. Virginia, 253 U.S. 412, 415 (1920) (emphasis added).

99. 404 U.S. 71 (1971).

100. A plurality of the Court did elevate sex to the level of a "suspect classification" in Frontiero v. Richardson, 411 U.S. 677, 682 (1973), finding "imphicit support for such an approach" in Reed. Id.

101. 404 U.S. at 73.

102. Id. at 76.

103. 421 U.S. 7 (1975). 
the Court found that a child support statute which required a husband to provide for his son until age twenty-one but entitled his daughter to support only until age eighteen imposed "criteria wholly unrelated to the objective of [the] statute."104

This method of analyzing the relationship between the means and ends of governmental regulation, which is concerned with the reality of the relationship rather than depending entirely upon the label attached to the right or classification, ${ }^{105}$ could also be appropriately apphied under the due process clause. Indeed, the language of Reed seems to have originated in Nebbia $v$. New York, ${ }^{106}$ a due process case (postLochner, pre-Skrupa) which required that "the ineans selected . . . have a real and substantial relation to the object sought to be attamed."107 The Court's refusal to restore this more stringent version of the "rational basis" test to due process analysis has had the not unpredictable effect of forcing litigants to construct their arguments in more "fashionable" equal protection terns. ${ }^{108}$ While such forensic adjustments may take care of many cases, there still remain certain kinds of governmental regulation which affect persons as individuals and not as members of a particular class, and which simply cannot be fit realistically into the equal protection mold. ${ }^{109}$ Laws governing the procurement

104. Id. at 14.

105. Professor Gunther described this new equal protection approach as an "intensified means scrutiny" which would "close the wide gap between . . . strict scrutiny . . . and . . . minimal scrutiny by raising the level of the minimal from virtual abdication to genuine judicial inquiry." Gunther, supra note 97, at 24. Thus, the Court would be compelled to "take seriously a constitutional requirement that has never been formally abandoned: that legislative means must substantially further legislative ends." Id. at 20.

106. 291 U.S. 502 (1934).

107. Id. at 525 .

108. See, e.g., Davis v. Weir, 497 F.2d 139 (5th Cir. 1974), striking down a city ordinance which permitted the municipal water department to terminate service to tenants of landlords who had failed to pay an outstanding bill even though the tenant's individual account was current. In order to bring the ordinance within the purview of the equal protection clause, the plaintiff alleged,-and the court agreed, that those seeking water services were divided into two categories: "applicants whose contemplated service address is encunbered with a pre-existing debt (for which they are not liable) and applicants whose residence lacks the stigma of such charges." Id. at 144. The court then applied the equal protection version of the "rational basis" test and found the classification to be unreasonable. Id. While the case is admittedly support for the argument that we need not worry about due process because all due process cases have some comparative aspects and are therefore susceptible to equal protection analysis, I think the case more clearly indicates that at soine point equal protection arguments become too tenuous. The court's acceptance of this artificial analysis can be attributed to its recognition that, unless it did so, this patently unfair ordinance would escape judicial review.

109. The distinction between equal protection and due process has been explained as follows:

Why equal protection rather than due process is called into play in any partic- 
of an abortion are an example, as are haircut regulations. ${ }^{110}$ In these cases, the fact that the individual right asserted inay or may not be deemed "fundamental" should not exempt the regulation from ineaningful judicial review. ${ }^{111}$ This is particularly so when the only apparent reason why the Court is gun-shy in cases arising under the due process clause is the fact that "due process carries a repulsive connotation of value-laden intervention ....,"112 as reflected in the disdain for Lochner.

I am not convinced, however, that Lochnering is an all-or-nothing proposition. I believe that our courts are perfectly capable of examining regulations which infringe upon less-than-fundamental rights in order to insure that the state does not act arbitrarily and that personhood is preserved to the maximum extent consistent with an orderly society. The equal protection cases support my confidence in the judiciary. ${ }^{113} \mathrm{In}$ addition, Professor Ely has pointed out that permitting courts to make case-by-case assessments of the reasonableness of regulations in the spirit of Lochner would be less "dangerous" to the Constitution than continuing to apply a Roe-type analysis. ${ }^{114}$ Lochner did not create any fundamental right. The Court simply asked if the legislation involved furthered some legitimate governmental objective. ${ }^{115}$ The verdict of

ular case is in the first instance a question of whether the law in issue attempts either to classify ostensibly different cases as similar or to make apparently similar cases different. Cases not imvolving some asserted form of one-for-one comparability with other cases, but raising solely questions of fair treatment, invoke due process rather than equal protection. Goodpaster, The Constitution and Fundamental Rights, 15 ARIz. L. REV. 479, 512 n.110 (1973).

110. Mr. Justice Douglas, dissenting from the denial of certiorari in Ferrell v. Dallas Independent School Dist., 393 U.S. 856 (1968), suggested that refusing to provide an education to male students wearing long hair is a denial of equal protection. Id. This approach was not adopted by any of the lower courts which overturned hair regulations. See note 47 supra.

111. Professor Goodpaster has suggested that, since both due process and equal protection are grounded in fairness considerations, claims arising under either clause can be measured by the same standard: "[T]he government must be fair, and the only way to determine whether it has been fair is to weigh and balance its purposes and method of regulation against the interests regulated and to examine, in view of the government's ends, the consequences of the regulation on the regulated." Goodpaster, supra note 109, at 513. I agree that the standard of reasonableness by which governmental regulations are measured should not vary with the constitutional guarantee which the action is alleged to have infringed. To a large extent, this Article represents an effort to show how ideas such as those discussed by Professor Goodpaster can be given practical effect by members of the judiciary.

112. Gunther, supra note 97 , at 42 .

113. See, e.g., Jefferson v. Hackney, 406 U.S. 535 (1972); Richardson v. Belcher, 404 U.S. 78 (1971) (in which the Court subjected state allocations of welfare benefits to minimal scrutiny and found them reasonable).

114. Ely, The Wages of Crying Wolf: A Comment on Roe v. Wade, 82 Yale L.J. 920, 940, 943 (1973).

115. Lochner v. New York, 198 U.S. 45, 58 (1905). 
history is that the Court misapplied this test; the state's interest in regulation of labor-management relations clearly outweighs an individual entrepreneur's right to run his own business. Roe, on the other liand, explicitly created a fundamental right to an abortion which can only be overcome by demonstrating a compelling state interest. ${ }^{116}$ This standard was applied despite the fact that, unlike in Griswold, ${ }^{117}$ the statute in Roe was found to promote a permissible governmental purpose, the protection of the mother's health. ${ }^{118}$

I think that this type of analysis is artificial and simply tends to obscure the way in which a particular decision was reached. ${ }^{119}$ As Learned Hand wrote, the term "fundamental" is one "whose office usually, though quite innocently, is to disguise what [judges] are doing and impute to it a derivation far more impressive than their personal preferences, which are all that in fact lie behind the decision." 120 When dealing with individual rights which are not specifically protected by the Constitution, the courts are simply engaged in a balancing exercise. The individual's right to be let alone must, in each instance, be weighed against the state interest asserted and the rationality of the means chosen to accomplish this objective. Two things are then obvious. First, in order for the balancing process to work properly, the operator of the scales must have all the facts. The state must be compelled to articulate its reasons for the regulation. Second, where there are no weights on the state's side of the scales, the individual's right of personhood must prevail. I believe that this is, in fact, the process which is employed by judges and that, in many cases, the labelling of an asserted right as "fundamental" simply means that it outweighs the asserted state interest in that particular imstance. ${ }^{121} \mathrm{I}$ also believe that the existence of such

116. Roe v. Wade, 410 U.S. 113, 155-56 (1973).

117. See notes $92-94$ supra and accompanying text.

118. 410 U.S. at 153-54; see Ely, supra note 114, at 941-42 \& n.117. An example of the unfortunate side effects of raising the right to an abortion to fundamental status is Friendship Medical Center, Ltd. v. Chicago Bd. of Health, 505 F.2d 1141, 1153-54 (7th Cir. 1974), cert. denied, 420 U.S. 997 (1975), in which the court decided that no health and safety restrictions, regardless of their reasonableness, could be placed on first trimester abortions.

119. "Indeed, all of our recent constitutional history would have been more coherent, and more satisfying to the Justices and to the various consumers of their constitutional product, had the Supreme Court never abandoned substantive due process but had merely excised its laissez-faire excrescence." Henkin, supra note 11, at 1427. See also Cominent, supra note 96, at 827-30.

120. L. HAND, THE BILL OF RIGHTS 70 (1958).

121. Professor Henkin has complained that, by continuing the present approach, we will know which rights are and which are not within the zone [of privacy] only case by case, with lines drawn and redrawn, in response to individual and 
ad hoc balancing should not be a source of fear which requires that reality be concealed. As Professor Sutherland observed, "If anyone rebels at the thought of entrusting this power to the nine Justices, he may well consider for a while to whoin he would prefer to entrust it; this can be a sobering experience."122

\section{CONCLUSION}

I think that the rights of man are literally innumerable, but that very few of them deserve to be labelled "fundamental." The remaining ones are of varying degrees of importance and are legitimately subject to regulation in pursuance of a countervailing state interest. Under the currently employed judicial method of vindicating individual rights, however, the state is given virtually complete discretion in the regulation of lesser rights, while being precluded from interfering with those rights deemed fundamental. This seems to me to be an extreme approach which blocks effective state action on one end while permitting unwarranted infringements upon personal liberty on the other end. I suggest that a preferable approach would be to concede the state's potential interest in any area and to litigate the extent of it. At the same time, I suggest that it would not be unfair to government to presuine the legitimacy of an asserted right of personhood and thereafter to direct inquiry to whether the state's interest is sufficiently strong to justify infringeinent. Results would largely depend upon fact determinations, the making of which is a traditional court function.

All of what I have said rests upon a crucial prenise: that government may not act capriciously and arbitrarily to make rules and law that do not bear a rational relationship to a legitimate governmental purpose. If I am wrong about that, I am wrong about all of it.

societal initiatives and the imaginativeness of lawyers. Henkin, supra note 11, at 1426 .

I believe that there are significant differences between the approach I am espousing and Mr. Justice Marshall's "sliding scale." His approach "clearly comprehends variations in the degree of care with which the Court will scrutinize particular classifications depending .... on the constitutional and societal importance of the interest adversely affected . . . ." San Antonio Independent School Dist. v. Rodriguez, 411 U.S. 1, 98-99 (1973) (dissenting opinion). Under my analysis, the initial task is to identify and weigh the state interest rather than to ascertain the "soeietal importance of the interest adversely affeeted." This procedural difference could be decisive in situations in which the individual and state interests are minimal. I would prefer that the close cases at this level be decided in favor of the individual.

122. Sutherland, Privacy in Connecticut, 64 MrcH. L. REv. 283, 288 (1965). 